\title{
FROM PORTUGAL TO
}

\section{THE COLONIES:}

\section{CHARACTERISTICS OF}

PORTUGUESE EXILIES ATT THE

END OF 18TH CENTURY

AUTOR/A: Liliana Andreia Valente Neves. University of Minho. Portugal.

CÓDIGO ORCID: 0000-0003-0941-7841

DOI: https://dx.doi.org/10.12795/crater.2021.i01.04

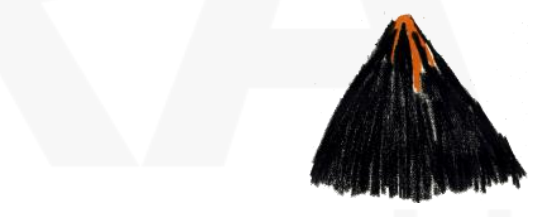

CRATER. ARTE E HISTORIA

e-ISSN: 2792-7709 


\title{
FROM PORTUGAL TO THE COLONIES:
}

\section{CHARACTERISTICS OF PORTUGUESE EXILIES AT THE END OF THE 18TH CENTURY}

\author{
Autor/a: Liliana Andreia Valente Neves*. University of Minho. Portugal. \\ Código ORCID: 0000-0003-0941-7841 \\ DOI: https://dx.doi.org/10.12795/crater.2021.i01.04
}

\begin{abstract}
The exile penalty has been widely used by the portuguese justice over the past centuries. The exiled were forced to cross the Atlantic in the direction of Brazil, Africa and Asia, where they fulfilled the punishment. The constant sending of large human contingents to colonial territories demonstrates the interests that the Crown had in removing the criminals from the metropolis. However, it can be an indicator of other objectives, such as the population and effective possession of the places where they were destined. This reality caused variations in the fate of the exiles according to the times and the needs that the Crown had in different periods. Thus, several authors agree that the sending of exiles to the colonies was aimed at occupation, defence, settlement and contribution to miscegenation in these territories. Through this research work, we seek to carry out a comparative
\end{abstract}

study where we highlight the differences between the sending of exiles to the South American and African colonial territories. We also seek to get to know these individuals seeking to know their social status, profession, crime, age, marital status, place of birth, destination of exile and time of sentence. It was also our intention to analyze how the process of sending these individuals overseas was carried out, the time between the condemnation and their departure, how they were shipped, who was in charge of taking them to their destination and who guaranteed their survival during the trip.

\section{KEYWORDS}

Exile; Crime; Colonies; Misericordias.

\section{DE PORTUGAL A LAS COLONIAS: \\ CARACTERÍSTICAS DE LOS DESTERRADOS PORTUGUESES A FINALES DEL SIGLO XVIII}

\section{RESUMEN}

La pena de destierro ha sido ampliamente utilizada por la justicia portuguesa en los últimos siglos. Los desterrados se veían obligados a cruzar el Atlántico en dirección a Brasil, África y Asia, donde cumplían el castigo. El envío constante de grandes contingentes humanos a los territorios coloniales demuestra el interés que tenía la Corona en sacar a los delincuentes de la metrópoli. Sin embargo, puede ser un indicador de otros objetivos, como la población y la posesión efectiva de los lugares a los que eran destinados. Esta realidad provocó variaciones en el destino de los desterrados según las necesidades que la Corona tenía en diferentes períodos temporales. Así, varios autores coinciden en que el envío de desterrados a las colonias tenía como objetivo la ocupación, la defensa, el asentamiento y la contribución al mestizaje de estos territorios. A través de este trabajo, pretendemos realizar un estudio comparativo donde destaquemos las diferencias entre el envío de convictos a los territorios coloniales sudamericanos y africanos. Buscamos, también, conocer a estos individuos y averiguar su estatus social, profesión, delito, edad, estado civil, lugar de nacimiento, destino de la deportación y momento de la condena. Asimismo, queremos analizar cómo se desarrollaba el proceso de envío de estos individuos al extranjero, el tiempo que transcurría entre su condena y su partida, cómo eran embarcados, quién se encargaba de llevarlos a su destino y quién garantizaba su supervivencia durante el viaje

\section{PALABRAS CLAVE}

Desterrados; Crimen; Colonias; Misericordias.

\footnotetext{
* This initiative was supported through the Multiannual Funding of the Landscape, Heritage and Territory Laboratory (Lab2PT), Ref. UID/04509/2020, financed by national funds (PIDDAC) through the FCT/MCTES. SFRH/BD/135711/2018
} 


\section{Introduction.}

The exile penalty began to be used in the Middle Ages and remained in the Early Modern Age, revealing itself as an important instrument for the Portuguese Crown. Exile was a long-used sentence in Portugal, which had the objective of removing the convict from his domicile (Oliveira Costa, 2018). Initially, the exiled were sent to sparsely populated territories in the interior of the kingdom. However, the destinations varied over the different periods, depending on the political needs of the crown. For this reason, Marta de Oliveira considers that the exiled were "at the service of building public order". Through the punishments they received, the exiles began to play a role of service to the kingdom, to the homeland (Oliveira, 1998). In other words, through exile, the Portuguese Crown sought to keep the miscreants away from the metropolis, using these human contingents to protect and colonize overseas territories (Marques, 2008). Charles Boxer was the first author to consider that exile served Portuguese imperial interests, followed by Timothy Coates (Coates, 1998; Oliveira Costa, 2018).

The terms degredo and desterro were synonymous in the Early Modern Period. They consisted of forcing someone to leave the Kingdom, the Court, the correição, the city, town, county, village, bishopric or archbishopric. It could also involve the obligation to go to a specific location, usually sparsely populated areas, such as some of the coutos or colonial territories (Correia, 1977). From the perspective of Oliveira Costa, the exile to which the convicts were voted was similar, on the one hand, to a pilgrimage to deserted places where the person would regenerate and, on the other, to isolation to avoid contagion by the plague (Oliveira Costa, 2018). The idea of the desert as a place of reflection and regeneration is biblical. However, as there is no desert in Europe, Jacques Le Goff considered that the forest took its place. That is where those who wanted to live alone, in meditation and regeneration, took refuge. It was also there that criminals and vagabonds, outlaws, marginalized people took refuge (Le Goff, 1985; Zocca, 2004; Oliveira Costa, 2018).

Despite the subject of exiles being of great relevance, it is still a subject very little studied by Portuguese historiography. Instead, it has been the target of some development in Brazil. We highlight the research by Simai Torres and Janaína Amado who worked on the same documentary series as us. However, while both were limited to individuals deported to the Amazon, we extended our analysis to those condemned to other overseas territories (Torres, 2006; Amado, 2000). More recently, the work of Thaís de Oliveira Costa was published, which focuses on those condemned to exile by the Portuguese Inquisition (Oliveira Costa, 2018). We also highlight the work of Juliana Diogo Abrahão on exiles to Angola, in the 18th century, based on the study of guide letters attributed to exiles (Abrahão, 2014).

Regarding Portuguese legislation about exiles, for the Early Modern Period, we highlight the works of Emília Viotti da Costa, António Manuel Hespanha and Eduardo Correia (Correia, 1977; Hespanha 1987; Costa, 1998). We emphasize, even though Oliveira Costa also focuses on the diversity of crimes punished with exile by 
ordinances, from crimes of a sexual nature, crimes against religion, witchcraft, among many others (Oliveira Costa, 2018). The same author refers to several researchers who have focused on the issue of exile in the cultural aspect, such as Laura de Mello Souza and Selma Pantoja. While the first will have considered that the exiles sent to Brazil allowed the propagation of heterodox religious practices, the second focuses on the issue of cultural miscegenation (Oliveira Costa, 2018).

For the elaboration of this work, we used a sample of 352 exiled people, between 1769 and 1787, to Portuguese colonial territories, located both in Africa and in America. The data was obtained by consulting the Fundo do Juízo dos Degredados, in the Archive of Torre do Tombo. We intend to present and discuss the crimes committed by the exiled, their age, their social status, the penalty, their duration, among other aspects.

\section{From crime to exile: characteristics of Portuguese exiles between 1769-1798.}

The shipment of criminals to the colonies turned out to be an opportunity for the Portuguese Crown to both empty the jails of the Kingdom from their occupants, and to aid in populating the overseas territories (Torres, 2006). According to jurist André Lamas Leite, there exists an inherent connection «between the deprivation of freedom, and the economic and financial needs of who's in power in a given moment» (Leite, 2019). The situation of the exiles is a good example of that, and of the way how the Portuguese authorities knew to take advantage of this reality. As such, exiles were sent in waves to the areas in Portuguese America that lacked in white population, due to them being unattractive to emigrants (Coates, 1998). Gilberto Freyre weighed that «the Portuguese Crown voluntarily exiled to Brazil men accused of sexual and moral crimes with the intent of having them procreate and help populate the region ${ }^{1}$ (Oliveira Costa, 2018). Were this to be true, it'd reveal a clear exploitation of those criminals who, in this way, began to serve national interests.

The main overseas locations where exiles were shipped to comprised of Africa and Brazil, as shown in graph 1 . Of the 352 cases we studied, we confirmed that $72 \%$ of the individuals were sent to African territories, and $23.8 \%$ to the Brazilian territories. Grão-Pará and Maranhão were two of the main destinations in Portuguese America where exiles were sent to. It's important to note that, despite the Ordenações Filipinas forbidding exiling women to Africa, (we confirmed that ten of the 31 we analyzed were sent to Angola, nine to Cabo Verde, nine more to Pará and two to Maranhão, with the destination of the remaining woman being unknown (Ordenações Filipinas, Livro V, Título CXL). So, of all the exiled women, nineteen were sent to Africa and only eleven were sent to Brazil. This same situation was verified by other authors (Abrahão, 2015). It is necessary to underline that the Philippine code dates from the beginning of the 17th century and our study focuses on the

\footnotetext{
${ }^{1}$ Translation by author.
} 
second half of the 18th century, so there have certainly been developments in penal practice.

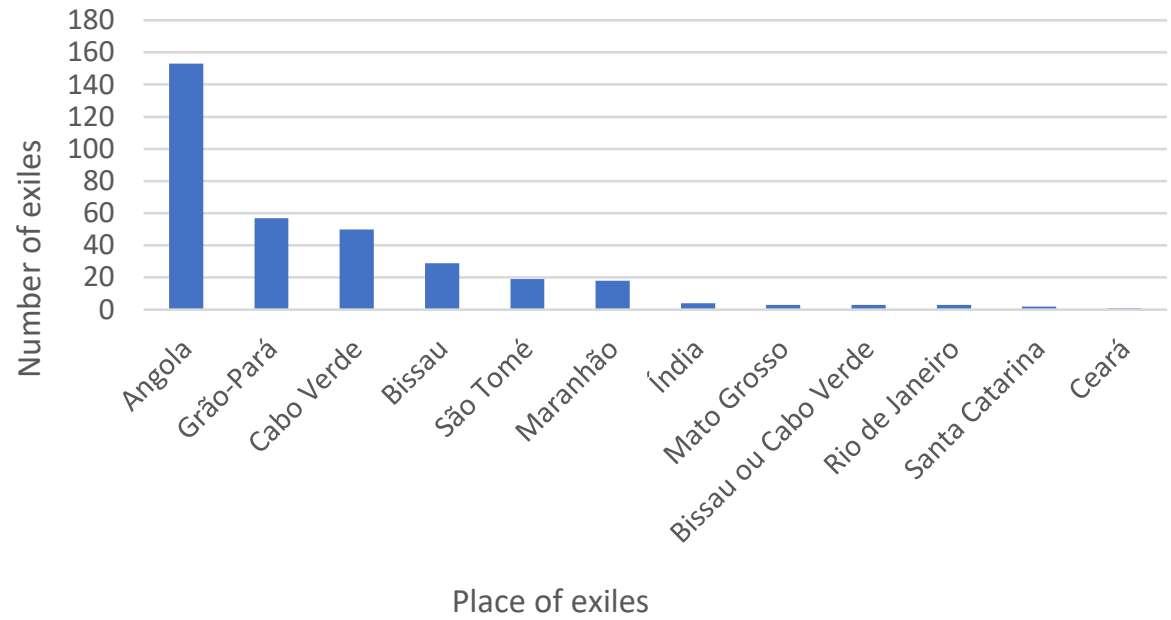

Graph 1. Destination of exiles sent overseas between 1769-1787. ANTT, Fundo do Juizo dos Degredados 1749/1833. Feitos Findos, Jizo dos Degredados, Livro n³5, 1769-1786; Livro n43, 1786-1798.

The preferential shipment of exiles to the African colonies, in relation to the American ones, is made obvious by the percentage difference. As it is known, during the rule of $D$. José I there were attempts to increase Portuguese presence and control in African territories. In 1762, Angola's governor would have asked the Secretary of Foreign Affairs to send exiles and couples to the colony, in order to populate it (Abrahão, 2015). Following the thought process of Charles Boxer, Selma Pantoja states that the 18th century was the height of exile shipments to Angolan territories, although the expulsion of gypsy people played its fair share in that situation (Pantoja, 2004). Even so, not all the exiled who arrived in Angola were treated the same. While a portion of them stayed in the urban centers, others were sent to the interior. Some of those managed to reach administrative positions or became slave merchants (Pantoja, 2004). Despite that, those success stories didn't stop the complaints by the local governments about the general insecurity and crimes brought on by the exiles. It got to the point where requests were made so the king would stop sending such dangerous people to Angola, due to the harm they caused (Abrahão, 2014).

Regarding the shipment of exiles to Brazil, although Thimoty Coates mentions how «Maranhão, Pará and other regions served as places of exile during the first half of the 17th century, being abandoned in the early 18th century and replaced by Ceará and [...] Mato Grosso» ${ }^{2}$, Simei Torres noted that people were still being exiled to the Amazon until the beginning of the $19^{\text {th }}$ century (Coates, 1998 through Torres, 2006). Our data related to late $18^{\text {th }}$ century also matches Torres'. We verified how, of the 352 cases we studied, only one person was sent to Ceará and three to Mato Grosso, while Pará and Maranhão got 75 exiles $^{3}$. The studies by Geraldo Pieroni led

\footnotetext{
2 Translation by author.

${ }^{3}$ Arquivo Nacional da Torre do Tombo [ANTT], Fundo do Juízo dos Degregados [FJD], Feitos Findos, Juízo dos Degredados 1749/1833, Livro n 35, 1769-1786.; Livro $n^{\circ} 43,1786-1798$.
} 
him to confirm that, while in the $16^{\text {th }}$ century an important share of the Brazilian population was comprised of exiles, the same does not apply to the following centuries (Oliveira Costa, 2018).

Besides overseas exile, people were also exiled to the galleys and to the coutos. Galleys were small vessels moved by rowing. Each oar required the strength of three or four men, meaning that between 90 and 240 men were needed to move the vessel (Braga, 1999). The work was so arduous, it necessitated slaves and criminals to do it. The physical strength necessary to move the galleys resulted in women, children and the elderly not being condemnable, as well as people considered to be of quality (Correia, 1977; Oliveira Costa, 2018).

Condemnation to the galleys would be a common practice in Castile and would have been practiced in Portugal during the Philippine government, having become less common after the end of the dynasty (Araújo, 1998). As such, being condemned to this sort of punishment would not always lead to working on the vessel, but rather hard labor in the construction and maintenance of naval vessels, or in construction work in the city of Lisbon (Braga, 1999). One of the pivotal moments in the History of the Kingdom when this resource was deployed occurred after 1755 earthquake. On November 4th, a law was enacted which enabled the condemnation of vagrants and beggars to work on reconstructing the city of Lisbon (Correia, 1977). In this regard, jurist André Leite contemplates those economic interests have always been connected to the history of punishment (Leite, 2019). Contrary to the demanding nature of forced labor, which those condemned to the galleys were subject to, those exiled to the coutos, and the colonies kept their freedom, but needed to work in order to guarantee their sustenance and survival (Oliveira Costa, 2018).

\subsection{Shipment of exiles oveseas.}

In the 17th and 18th centuries, it was common practice for the Misericórdias of Minho to help send people to Brazil. The requests for aid with paying for tickets or money for the trip that we studied were, for the most part, made between the months of October and January, with some also being made in May, June and September. These data may be indicative that the fleets headed towards Vera Cruz would make use of the time of year when the weather conditions would be more favorable for the trip - in March and April. Despite that, sometimes, the departures could be extended from February until May, to avoid sailing against the monsoons that could possibly cause delays of several months (Palacin, 1971). On the other hand, departures for Angola, Cabo Verde and Bissau happened all year long, except in August.

By analyzing the boarding records, we verified that between the sentence and the shipment of the exiles it took from nine months to a year, in average. It is also necessary to subtract the time spent between taking them from their place of origin to Lisbon, where they would board ${ }^{4}$. That situation was foreseen in the Ordenações,

\footnotetext{
${ }^{4}$ ANTT, FJD, Feitos Findos, Juízo dos Degredados, Livro n 43, fls.4-41.
} 
which established one year after the condemnation as the due date for shipping exiles.

Those sentenced to exile were taken by the Juízes de Fora of their judicial districts, fettered and on foot, until the next judicial district, passed from one to the next successively until reaching Lisbon, where they'd be kept in the prison of Limoeiro. For the trip, the exiles carried a letter with them that they'd show the captain of the ship, who had a year to show evidence of their shipment to the magistrates of the place of exile (Costa, 1998; Torres, 2006; Oliveira Costa, 2018). Those exiled to Brazil received «lands, seeds, animals and tools [...] money for transportation and initial expenses, cows, bulls, mares and common tools» ${ }^{5}$ to begin their life in that new land (Torres, 2006). In other words, they were given some assets in order to be able to begin a new phase of life.

Regarding those exiled to the coutos in the interior of the Kingdom, like Castro Marim and Miranda do Douro, they would have gone alone to their destination, unfettered and unsupervised. Along the way, and in their destination, they'd resort to outside charity, especially that of the Misericórdias (Oliveira Costa, 2018).

\section{Reasons for exile and social characteristics of the inmates.}

Of the 352 cases of exile we analyzed, we managed to ascertain the crimes committed by only 146 of them, which equals about $41 \%$. As for the others, we do not have any information regarding the motive for their expulsion. We confirmed that seventy-two of them committed theft, and thirty committed murder. In the data gathered by Simei Torres for those exiled to the Amazon between 1750 e 1800, 18\% of the crimes were, precisely, thefts and others of a similar nature (Torres, 2006) [table 1].

According to the penal methods of the time, petty theft could incur rather heavy sentences. A number of exiled from the Kingdom incurred in crimes that, nowadays, wouldn't be considered serious (Costa, 1998). Such were the cases of the man who cut some vines, two others who were convicted for blasphemy, two women convicted for being accomplices and lovers of thieves, among others shown in the table above. Something to keep in mind is how, in this time period, sometimes the meaning of the act weighed more than the act itself; meaning that the severity may not be due to the crime. For instance, the use of weapons could be irrelevant. What mattered was disobeying and hindering public order (Hespanha, 1987). Insulting someone could not only hurt their honor, but also their family's honor, sometimes leading to quarrels, dules and rivalries, which, again, could hinder public order (Hespanha, 1987). Physical strikes, such as slaps, stabs or stone throwing, could be severely punished if they caused the body to become deformed. Besides being considered an element of God's work, the body could have economic vale, like those of single women and slaves (Hespanha, 1987).

\footnotetext{
${ }^{5}$ Translation by author.
} 


$\begin{array}{lr}\text { Crimes } & \begin{array}{r}\text { Number } \\ \text { sent overse }\end{array} \\ \text { Theft } & 72 \\ \text { Murder } & 3 \\ \text { Escape from exile } & 7 \\ \text { Vagabond } & 6 \\ \text { Hurt another person } & 6 \\ \text { Desertion } & 4 \\ \text { Use of knives or weapons } & 4 \\ \text { Adultery } & 3 \\ \text { Blasphemy } & 2 \\ \text { False Oath } & 2 \\ \text { Accomplice and lover of thieves } & 2 \\ \text { Took off a public notice of the Real Mesa Censória } & 1 \\ \text { Found next to a convent with a fair } & 1 \\ \text { Corresponded with the Jesuits of Rome } & 1 \\ \text { Coused a riot } & 1 \\ \text { Counterfeiting Money } & 1 \\ \text { Desobedience to superiors } & 1 \\ \text { Misrouted Royal Treasury assets } & 1 \\ \text { Cut vines } & 1\end{array}$

Table 1. Crimes committed in Portugal, by exiles sent overseas, between 1769-1787. ANNTT, Fundo do Juizo dos Degredados 1749/1833. Feitos Findos, Juizo dos Degredados, Livro n³5, 1769-1786; Livro n43, 1786-1798.

Portugal resorted to exile to such an extent that Francisco Adolfo de Varnhagen regarded the Ordenações Filipinas as being excessively severe, given the way it was used to punish «very light offenses and even small sins» ${ }^{6}$ (Varnhagen, 1962 through Oliveira Costa, 2018). Jurist Vasco Homem de Melo, in the 1940s, also expressed surprise to how «the entire Portuguese nation wasn't exiled, considering the ubiquity of the Ordenações sentences» ${ }^{7}$ (Melo, 1940 through Oliveira Costa, 2018). In Livro $V$ of the Ordenações Filipinas, there were 265 crimes punishable by exile, with Africa being one of the destinations preferred by the Portuguese penal code (Toma, 2013). António Manuel Hespanha notes how exile frequently served as a substitute for the death penalty, and that some jurists considered that the capital punishment of the time tended to lead to the civic death of an individual - their exile - rather than their natural death. The frequency of the death penalty in Ordenações Filipinas led to the creation of a law that imposed the obligation of the resource at the Crown, in order for her to assess the case in depth. In addition, the courts listed a series of mitigations, to delay the death penalty, or to commute or pardon it. Through these actions the benevolence and grace of kings was exhorted, who attributed their

\footnotetext{
${ }^{6}$ Translation by author.
}

${ }^{7}$ Translation by author. 
pardon to the damned (Cortes, 1998). However, enlightened despotism brought with it changes to the way the Crown enforced the law. During mid- $18^{\text {th }}$ century, as a way to assert itself has the guarantee of social order and harmony, the monarchy escalated the punishments and increased the frequency of death penalties (Hespanha, 1897).

Murders made up for a considerable share of the motives for exile. Among the thirty homicides, eight were committed between spouses, namely six women who killed their husbands, and two men who killed their wives. For the most part, these crimes were punished with ten years of exile or permanent banishment. Some of them, however, resulted in four and eight years of exile. Women seemed to incur in this type of offense more frequently, with it being a way for them to free themselves from their husbands' oppression. In a study carried out by Maria Antónia Lopes, on women sentenced to death in Portugal, in the modern period, it appears that most of them were married and $47 \%$ of their victims had been their own husbands. Among the methods used for their annihilation would be blows with hoes, shots with rifles, strangulation, suffocation and poisoning. Although the latter is one of the methods traditionally attributed to murderers, surprisingly, only one of those sentenced to death, between 1693 and 1800, used this technique to kill their spouse. For this purpose, she used nitric acid and arsenic (Lopes, 2015). According to Alexandra Esteves one of the most used poisons was arsenic due to its cheap price and being used in the fields to kill mice (Esteves, 2014).

We also verified that only one of the three individuals punished for adultery was female. The other two were men, possibly convicted for getting involved with married women. This is because an adulterer, according to the Ordenações Filipinas, was not the one who betrayed his wife, but the man who gets involved with a married woman. At the time, only the women were «demanded to be faithful to the spouse» (Esteves, 2011).

Roman law only regarded adultery to be applicable to married women and their lovers, with single women or married men not being accused of such a crime. This difference was related to the subject of fatherhood and patrimonial passing. In other words, there could be no doubts regarding who the father of a child was. An adulterous woman would bring that doubt to within the family because she could be impregnated by another man and give the bastard child access to her husband's inheritance (Hespanha, 1987). According to Hespanha, Portuguese orders followed Roman Law, and that's why it was infrequent for husbands to be convicted for adultery.

We didn't find any differences in the choice of the place of exile according to the offense nor the sex of the offender. Despite that, it should be noted that those who escaped exile in Africa would be sentenced to be sent to Brazil, and those who ran away from there would have their sentences doubled (Ordenações Filipinas, Livro V, Título CXLIII). Given the risk of being convicted again or having their sentences increased, runaways were rare, but Hespanha considers that the control over that was limited (Hespanha, 1987) [graph 2]. 
Regarding the more common sentences, five years of exile made up for $28 \%$ of convictions, with ten years and permanent exiles corresponding to $20 \%$ and $21 \%$, respectively. Other authors confirmed the same spread (Torres, 2006; Abrahão, 2015). Nevertheless, the Ordenações Filipinas stated that no one should shipped to Brazil for less than five years, with lesser sentences being served in Africa or inside the Kingdom, preferably (Ordenações Filipinas, Livro V, Título CXL). But these provisions weren't always fulfilled. We found ten individuals sent to Pará and Maranhão with sentences of two, three and four years, respectively. Note that the Ordenações Filipinas were elaborated in the beginning of the 17th century, and the penal practice underwent alterations later. If, for example, during the Pombal government there was an upsurge in the application of severe penalties, on the other hand, in the reign of D. Maria I, humanitarian doctrines disseminated by Beccaria and Filangieri, from 1764 onwards, arrived in Portugal, that making the Portuguese courts more humanized (Cruz, 1981) [graph 2].

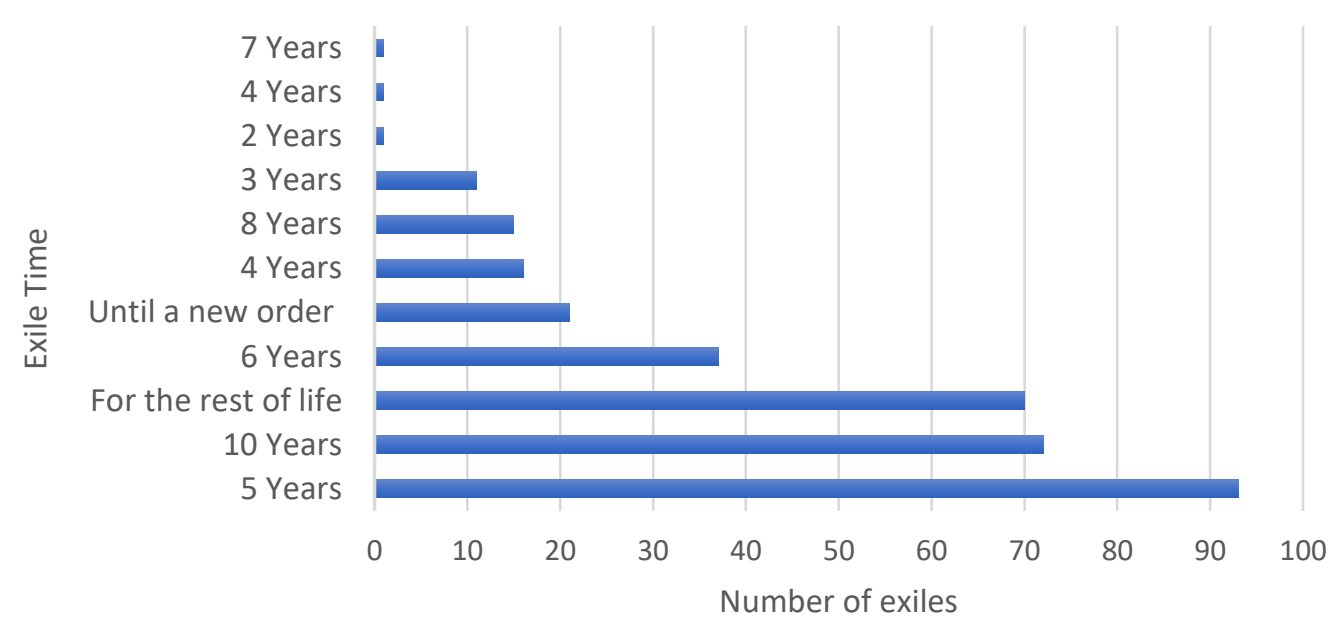

Graph 2. Penalties to be served by exiles sent overseas, between 1769-1787. ANTT, Fundo do Juízo dos Degredados 1749/1833, Feitos Findos, Juízo dos Degredados, Livro n³5, 1769-1786; Livro n 43, 1786-1798.

Twenty-eight of the seventy convicted to exile for perpetuity were subjected to the death penalty in case they returned to the Kingdom, and twenty-three of the convicts were subjected to lashes, proclamations and dragged by rope through the public streets before being shipped overseas. Two of them committed crimes of such violence that they were marked, with the intention of having everyone who laid eyes upon them know of their criminal status ${ }^{8}$. It should be mentioned that the Ordenações Filipinas stopped imposing sentences of fire branding and ear cutting. Even so, as has been noted, the legal specifications weren't always followed (Correia, 1977). But not everyone was subject to this kind of punishment. Some, due to privilege or lineage, couldn't receive despicable sentences, such as the nobility and their squires, judges, councilmen and prosecutors of municipalities and villages,

\footnotetext{
${ }^{8}$ ANTT, FJD, Feitos Findos, Juízo dos Degredados, Livro $n^{\circ} 35$; Livro $n^{\circ} 43$.
} 
boatswains and captains of topsail ships, relatives of judges of the High Court, knights by bloodline, and fur traders. For them, the sentences were substituted for two years of exile in Africa, and for those who were shipped to Brazil, the lashes were exchanged by an additional year. Those sentenced to lifelong exile would be dragged through the city or village, with a «cadea» in their feet, because their time in the colonies could not be extended further. However, when the offense in question was «against the crown, sodomy, false oath, counterfeiting money, theft, witchcraft, gossiping», ${ }^{9}$ there was no kind of sentence exchange (Ordenações Filipinas, Livro V, Título CXXXVIII) [graph 3].

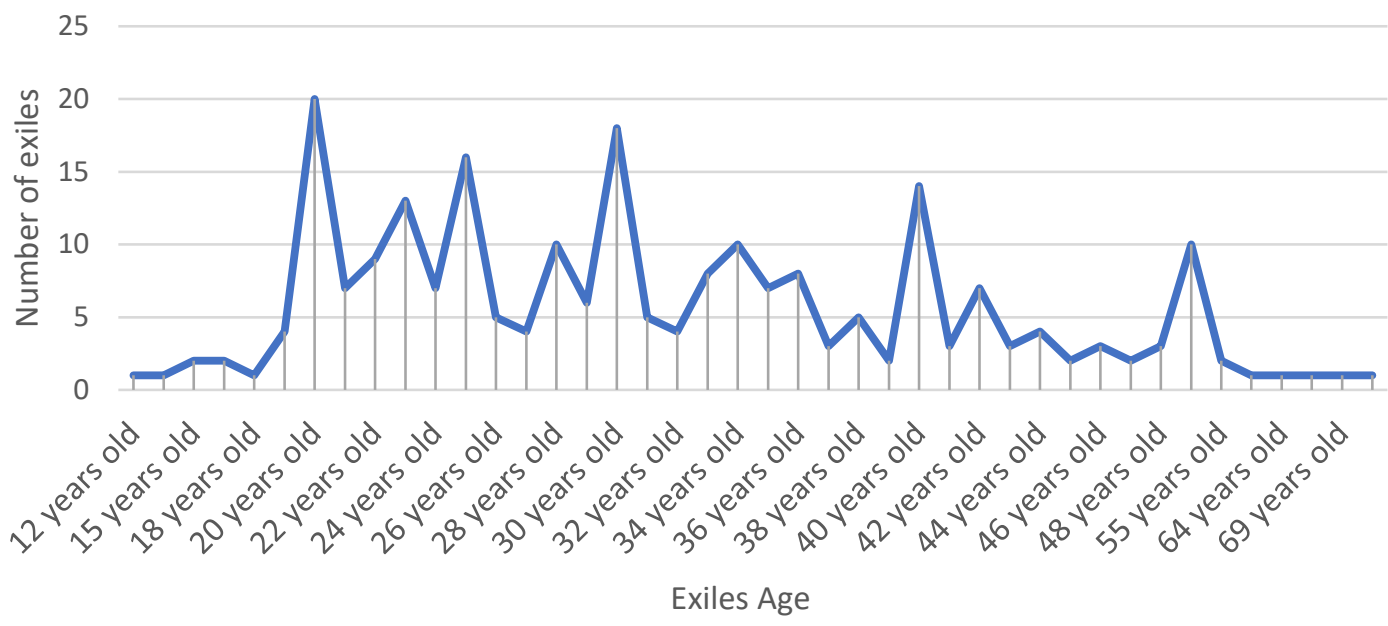

Graph 3. Age of convicts sent overseas, between 1769-1787. ANTT, Fundo do Juízo dos Degredados 1749/1833, Feitos Findos, Juízo dos Degredados, Livro n³ 35, 1769-1786; Livro $n^{\circ} 43$ 1786-1798.

Among the 236 analyzed cases, we managed to determine the age of the convicts and verify that $76.7 \%$ of them were between twenty and forty years old, which means that they were in the most active period of their lives. This same predominance in age range was noted by Juliana Abrahão and Simei Torres, with the latter commenting on how the preference for the exile of people at the peak of their lives could be indicative of the intentions the Crown had for them overseas - start a family, and colonize and protect the territories (Abrahão, 2015; Torres, 2006).

Opposite that we have two young boys, one aged twelve and the other fifteen. José António, fifteen years old, was exiled for six years to Maranhão for stealing from his master ${ }^{10}$. João Baptista was only 12 years old and was convicted to five years in exile in Grão-Pará ${ }^{11}$. There is no indication of him accompanying an exiled relative, unlike what sometimes happened, nor of his offense. We do know, however, that some exiled youth had been punished for disobeying their parents. Such was the case of Valentim Ferreira, aged seventeen years old, sentenced to three years of exile in Maranhão, for being a vagabond and disobeying his father ${ }^{12}$. The same

\footnotetext{
${ }^{9}$ Translation by author.

${ }^{10}$ ANTT, FJD, Feitos Findos Juízo dos Degredados, Livro $n^{\circ} 43, \mathrm{fl} .23$.

${ }^{11}$ ANTT, FJD, Feitos Findos Juízo dos Degredados, Livro $n^{\circ} 34$, fl.117v.

${ }^{12}$ ANTT, FJD, Feitos Findos, Juízo dos Degredados, Livro $n^{\circ} 43, \mathrm{fl} .23$.
} 
happened to Agostinho Pereira, whose parent accused him of using weapons and assaulting a person. For that reason, he was exiled for six years to the same place as Valentim ${ }^{13}$. As we can see, the age of the convicted may lead to mitigating their sentence (Correia, 1977). It should be noted that, in this period, the legal age of majority was only reached at twenty-five years of age. However, their resulting punishments would be harsh, and exile seems to have been a possible solution used to correct the behaviors of these young people still consumed by the effusiveness of adolescence [graph 4].

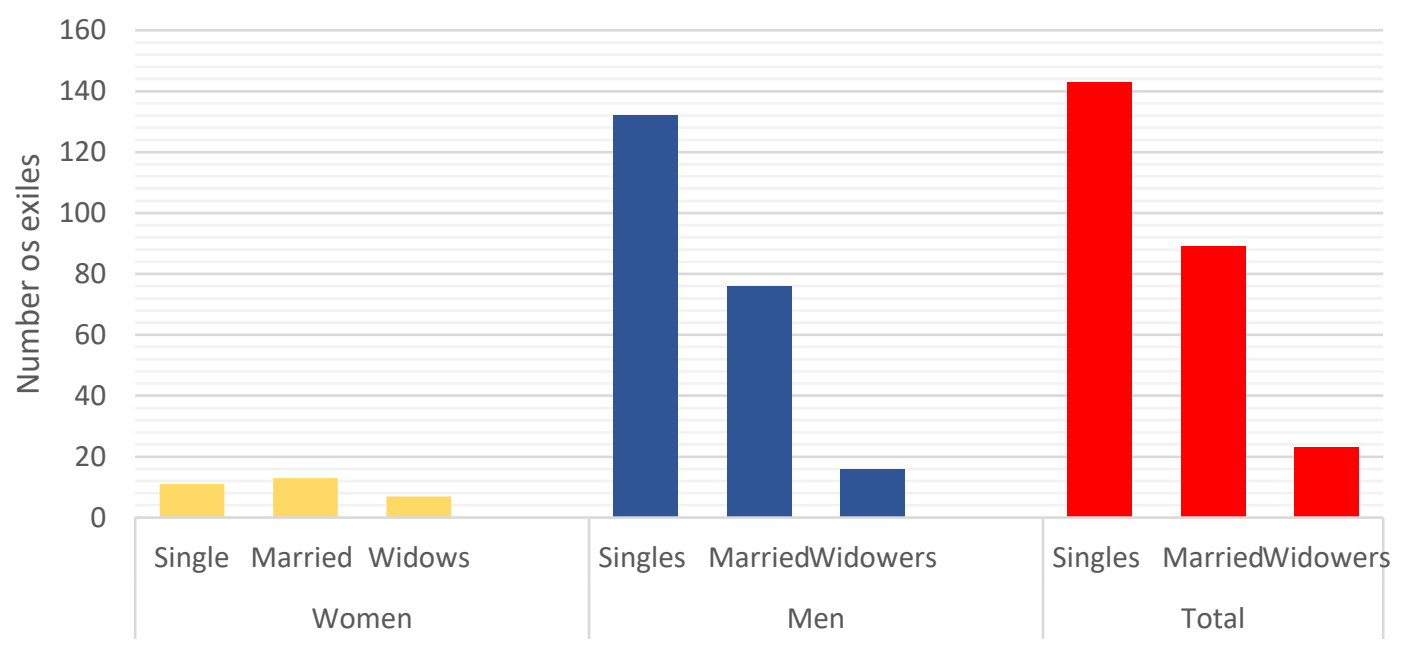

Exiles marital status

Graph 4. Marital status of convicts sent overseas between 1769-1787. ANTT, Fundo do Juízo dos Degredados 1749/1833, Feitos Findos, Juízo dos Degredados, Livro n 35, 1769-1786; Livro n 43, 1786-1798.

In the same manner the age range shows the interest of the Portuguese government in shipping active people, so does their marital status. There's a preference for single people, which could be indicative of less attachment to family and avoid escaping from exile. Another matter relates to how married individuals would frequently be exiled with their families in tow. If the Kingdom needed to restrain the exodus of the population, sending whole families overseas wouldn't be beneficial, contrary to sending unmarried people. For example, João Pedro Freire was given a life sentence in Ceará, taking with him his wife, five underage children, and a slave. Or João Batista, also sentenced for life in Angola and risking the death penalty in case he ever returned, who took with him his eight-year-old son ${ }^{14}$. There were other instances of women who voluntarily decided to accompany their husbands, or individuals who boarded sometime after their spouses with the intention of joining them ${ }^{15}$. Finally, another possibility for the high number of unmarried exiles could relate to the interest of Crown in sending unaccompanied

\footnotetext{
${ }^{13}$ ANTT, FJD, Feitos Findos, Juízo dos Degredados, Livro $n^{\circ} 43$, fl.23.

${ }^{14}$ ANTT, FJD, Feitos Findos, Juízo dos Degredados, Livro $n^{\circ} 43$, fl.40v.- fl.35.

${ }^{15}$ ANTT, FJD, Feitos Findos, Juízo dos Degredados, Livro $n^{\circ} 35$; Livro $n^{\circ} 43$.
} 
individuals due to them being more predisposed to serve in defending the territory and contributing to miscegenation (Torres, 2006).

Regarding the biological sex of the exiles, we verified that $91 \%$ were men, and only $9 \%$ were women. This discrepancy may be explained through the opinions of the time on women being inferior and incapable, which led to the law not being carried out in the same was as it did men, with the sentences being lighter. Sometimes, they were sentenced to exile in other Portuguese villages, like Castro Marim (Torres, 2006). Juliana Abrahão also verified that, from 1714 until 1756, of 1.141 individuals exiled to the same colony in Angola, $86 \%$ were men and only $11 \%$ were women (Abrahão, 2015). The coutos were «privileged lands with a special status». The couto of Castro Marim would have been created in 1421 and was one of the most important in Portugal. Typically, they were located in areas the crown wanted to populate. Despite being dissolved in the late 16th century, the coutos became active again between 1703 and 1790 (Oliveira Costa, 2018). Some of those exiled to colonies, due to being very young or very old, managed to have their sentences exchanged to the coutos, although their duration would end up doubled (Correia, 1977).

It should be stressed that, of the thirty-one exiled women, six killed their husband and two were lovers of thieves, meaning they were part of a gang. Selma Pantoja confirmed that 234 were sentenced by Lisbon's Inquisition to exile in Angola, between the $17^{\text {th }}$ century and the first half of the $18^{\text {th }}$ century, with most of them being between twenty and forty years old. According to the author, the crimes committed by the women were inherently related to their marital status. Single women were usually convicted for crimes of infanticide, for widows it was murder and poisoning, and married women were most commonly committed for theft and homicide (Pantoja, 1998 through Abrahão, 2015).

When comparing the circumstances of the exiles with general criminality, we verify that the data is slightly different, while keeping the same trend. Focusing on studies done for Vila Nova de Cerveira in the late 18th century, $74 \%$ of the accusations were against men, and $26 \%$ of them against women (Esteves, 2010). It was common for women to incur in delinquency, particularly in theft and slander, although the European average for that is only of 15\% (Esteves, 2010). Also, regarding Coimbra, Maria Antónia Lopes noted that in the prison in Portagem, between 1750 and 1849, of the 2978 convicted there, only 490 were women and 2308 were men (Lopes, 2013) [table 2].

Table 2. Origin places of Portuguese foreign exiles sent overseas between 1769-1787. ANTT, Fundo do Juízo dos Degredados 1749/1833, Feitos Findos, Juízo dos Degredados, Livro n³ 35, 1769-1786; Livro n 43, 1786-1798.

$\begin{array}{ll}\text { Exiles' Origin } & \mathbf{N}^{\mathbf{o}} \text { of exiles } \\ \text { Brazil } & 12 \\ \text { Spain } & 8 \\ \text { Genoa } & 3 \\ \text { Bissau } & 1 \\ \text { Mozambique } & 1 \\ \text { Germany } & 2\end{array}$


The fame Portugal gained during the Age of Discovery attracted many businessmen there. In the Kingdom lived Leonese people, Castilian, Napolitan, Lombard, Flemish, German, Galician, among others, with the Galician being very present in the Entre Douro e Minho region (Lopo, 2003; Alves, 2002). The term «Galego» is one such example, being used in documentation as a surname for individuals from Galiza who lived and worked in Minho (Neves, 2017). Some were merchants, while others were beggars who lived thanks to others' charity and ended up embroiled in criminality (Serrão, 1979; Alves, 2002). Maybe it's for that reason that we found twenty-seven foreigners living in Portugal exiled to the Kingdom's colonies. Twelve exiles were originally from the "States of Brazil", eight from Spanish towns, three Genoese - a servant and a blacksmith - one from Bissau, another from Mozambique, and two Germans, one of which was a gypsy fishmonger ${ }^{16}$ [map 1].

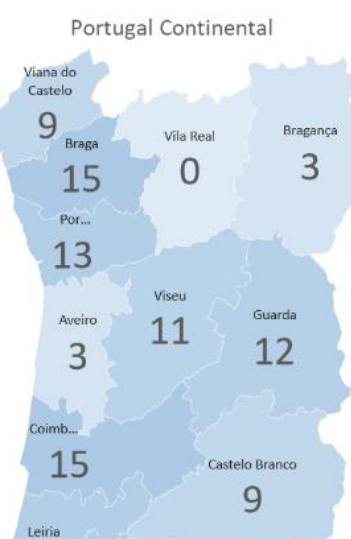

13
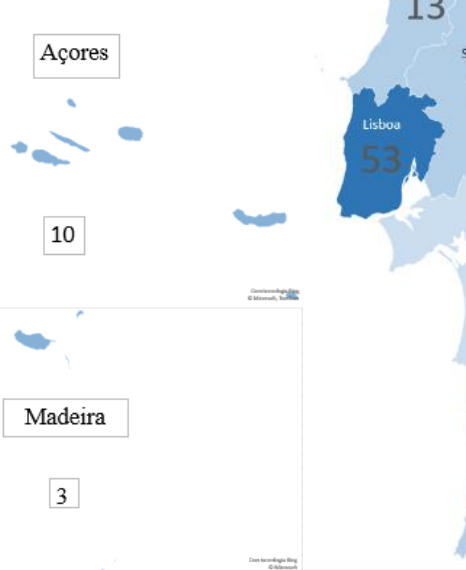

13
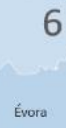

11

6

11

13

\begin{abstract}
Map 1. Distribution, by district, of Portuguese exiles sent overseas, between 1769-1787. ANTT, Fundo do Juízo dos Degredados 1749/1833, Feitos Findos, Juízo dos Degredados, Livro $n^{\circ} 35$, 1769-1786; Livro $n^{\circ} 43$, 1786-1798.
\end{abstract}

Regarding the exiles' birthplace, we grouped them by district, based on Portugal's current district map. This way, we verified that of the 231 exiles whose birthplace we were able to ascertain, most of them belonged to the district of Lisbon, followed by Braga and Coimbra. It should be noted that, at the time, Lisbon was a

${ }^{16}$ ANTT, FJD, Feitos Findos, Juízo dos Degredados, Livro nº 35; Livro n 43. 
bustling region. The capital was the most populated city in the Kingdom and one of the most populated in Europe. However, other regions also experienced a constant flux of outsiders, like Minho (Neves, 2017). The presence of foreigners was even clearer in the biggest Portuguese port town, where many ended up settling down.

Usually, those condemned to exile were taken in "levas" from their places of origin until Lisbon, where they boarded. However, in 1632, the Misericórdia of Viana da Foz do Lima managed to obtain royal permission for the ships that were docked in their village and headed to Brazil to take the exiles, so that the Santa Casa could reduce its expenses with them (Magalhães, 2017). It should also be mentioned that the convicted beggars financed by the Santa Casa of Lisbon should be shipped first, in order to alleviate their fellowship expenses (Ordenações Filipinas, Livro V, Título $\mathrm{CXL}$ ). That same privilege was then extended to all the Misericórdias. The high costs of the prison, which it charged on the prisoners or on the Misericórdias, during the several months or years in which they were waiting for a sufficient number of convicts to gather to constitute a "leva" or for a vessel to be available from the destination, made the Crown, from the beginning of the 17th century, to order prisoners sentenced to exile to remain free until their departure, reducing the financial burden on their incarceration (Araújo, 1998). Note that the exiles didn't travel in ships prepared specifically for them. As a way to lessen the transportation expenses, the Crown would send them in the merchant ships that were docked in Lisbon's port and would soon leave for the colonies ${ }^{17}$ [table 3].

$\begin{array}{lr}\text { Occupations } & \mathbf{N}^{\mathbf{0}} \text { exiles } \\ \text { Soldier } & 28 \\ \text { Worker } & 26 \\ \text { Religious } & 14 \\ \text { Sailor } & 13 \\ \text { Almocreve } & 11 \\ \text { Shoemaker } & 7 \\ \text { Surgeon } & 6 \\ \text { Carpenter } & 5 \\ \text { Servant } & 5 \\ \text { Barber } & 4 \\ \text { Jesuit } & 4 \\ \text { Days worker } & 4 \\ \text { Farmer } & 4 \\ \text { Traveling salesman } & 3 \\ \text { Infantry Colonel } & 3 \\ \text { Host } & 2 \\ \text { Student } & 2 \\ \text { Cattle herder } & 2 \\ \text { Tabacco Officer } & 2 \\ \text { Goldsmith } & 2 \\ \text { Doorman } & 2 \\ \text { Locksmith } & 2 \\ \text { Maker Tents } & 2\end{array}$

Table 3. Occupations of exiles sent overseas, between 1769-1787. ANTT, Fundo do Juízo dos Degredados 1749/1833, Feitos Findos, Juízo dos Degredados, Livro $n^{\circ} 35$, 1769-1786; Livro $n^{\circ}$ 43, 1786-1798.

\footnotetext{
${ }^{17}$ ANTT, FJD, Feitos Findos Juízo dos Degredados, Livro $n^{\circ} 35$; Livro $n^{\circ} 43$, fl.1.
} 
We managed to ascertain 181 occupations among the 352 exiles and noted a clear prominence of men related to the military. It's possible that the State used these trained contingents to take up the defense overseas (Coates, 1998). Soldiers and workers are also the main jobs Simei Torres gathered regarding individuals sent to the Amazon in the second half of the $18^{\text {th }}$ century (Torres, 2006).

\section{Exile and poverty: how the Misericórdias helped the exiled.}

Of all the cases we analyzed, only two of them were forced to pay for the expenses of their punishments. One of them was António Francisco, an oven owner from Braga, who was shipped on May of 1773 to Angola, for five years. He had been convicted for assaulting someone, and had to pay 50.000 réis to cover the Porto's Court of Appeal's expenditures. The other was Luís Gonçalves, a tobacco worker from Chaves, exiled for ten years in Angola and obliged to pay 100.00 réis for the Court's expenses ${ }^{18}$.

It was usual for the exiles with no financial resources to ask for the Misericórdias help with their expenses. The archives of these institutions give us many examples of that. In 1783, the Santa Casa of Braga helped five convicts by giving them a mount to go to the boarding location, and some alms of 1.400 réis for the trip, so they could feed themselves ${ }^{19}$. Also, in the administrative year of 1602-1603, the Santa Casa of Viana da Foz do Lima spent 1.520 réis on an exiled, so they could buy clothes for the trip, and helped Salvador Miranda, who received 2.000 réis to serve his exile (Neves $2017)^{20}$. In 1635, the Santa Casa of Ponte de Lima helped a convict who went to Brazil with 500 réis; a comparatively low amount ${ }^{21}$.

Going by existing studies, for the Santa Casa da Misericórdia of Porto, we know that the exiles travelled in uniform. For the men, these were made up of «a short coat and shorts of blue baize, shirt, buckled shoes, socks and a cap», and "a short cloak, jerkin, and dressing gown of blue baize, and a shirt» ${ }^{22}$ for the women (Cardoso, 2006) ${ }^{23}$. Sometimes, the Misericórdia dressed these individuals up inside the ships, and left them dishes and food for their time at sea. Amongst the variety of foods, the Santa Casa of Porto gave the exiles in mid-18th century, codfish was one of them, given how easy it is to conserve when salted (Cardoso, 2006).

The Santas Casas had a paramount role in helping poor convicts. According to Laurinda Abreu, of all the requests made by convicts and received by the Misericórdias, 50\% were successfully resolved (Abreu, 2014). The role these guilds had in helping the less fortunate, namely the convicts, was of great importance, and becomes even more relevant when we realize the state of degradation in the

\footnotetext{
${ }^{18}$ ANTT, FJD, Feitos Findos, Juízo dos Degredados, Livro n 35, fl.17v., fl.44.

${ }^{19}$ Arquivo Distrital de Braga [ADB], Fundo da Sabta Casa da Misericórdia [FSCMB], Livro de Termos n 19, fl.111.

${ }^{20}$ Arquivo Distrital de Viana do Castelo [ADVC], FSCMVC, Livro de Receita e Despeza 1602-1603 n 3.22.3.1, fl.12.

${ }^{21}$ Arquivo de Santa Casa da Misericórdia de Ponte de Lima [ASCPL], Livro de receita e despeza ano de 1635 para $1636 \mathrm{n}^{\circ} 453, \mathrm{fl} .5$

22 Translation by author.

${ }^{23}$ Cardoso, Maria Teresa Costa Ferreira, «A Cadeia da Relação e a assistência...», pp. 358-359.
} 
Portuguese jails of the time. They were filthy places, where diseases easily ran rampant due to their unhealthiness and lack of hygiene (Araújo, 1998; Lopes, 2010). It should be noted that, at the time, only rarely did the jails have a repressive nature. Their function was, usually, a preventive one, being the place where individuals awaited their trial. It could also have a coercive nature, forcing the payment of a financial fine (Correia, 1977). With no way to earn money to support themselves, convicts were dependent on the charity of others, giving monumental importance to the work done by the Misericórdias to guarantee they were fed. However, oftentimes, the aid given by the friaries was much vaster, encompassing other works of mercy (Magalhães, 2017).

\section{Final Considerations.}

Resorting to exile with convictions was quite frequent throughout the Early Modern Age in Portugal. They often replaced the natural death penalty, and represented the civil death of individuals, punishing criminals by moving them away from the territories where they had their social networks. It should be noted, however, that these individuals continued to play an important social role, in the territorial administration of Portuguese possessions.

If the death penalty led to the irremediable loss of useful human contingents, the civil death allowed its use in new social contexts. Thus, the exile took several forms, with the convicts being sent overseas, to the coutos, to the galleys, or simply forced to leave the county or district where they lived. In this way, exiles were used to populate border territories where it was necessary to establish a Portuguese presence, ensuring the effective defense and possession of those spaces. They were sent with the intention of populating the overseas territories with white individuals, promoting miscegenation and defending those places from the threats that shadowed them. Finally, these contingents were used for patrolling the Portuguese sea coast, defended by the Kingdom of corsairs who attacked their vessels, and some also worked on essential works for national reconstruction.

As such, we verified that the theme of exiles is broad and complex, since it went beyond the intention of punishing criminals, and aimed to take advantage of these individuals to be used according to the interests of the Kingdom. Thus, we found that most of the exiled were men, of working age, sent to territories where there were strong threats, and where Portugal wanted to increase white influence and presence. In the years we analyzed, these contingents were essentially sent to Angolan territory, which was consistent with an attempt to reaffirm the Crown's ownership of these locations.

\section{References}

Printed Fonts

Bluteau, R. (1970). Diccionário da Língua Portugueza composto pelo padre D. Rafael Bluteau, reformado, e acrescentado por Antonio Morais Silva, Tomo I. Oficina de Simão Thadeo Ferreira. www.brasiliana.usp.br 
Ordenações Filipinas. Livros IV e V. Edição «fac-simile» da Edição de Cândido Mendes de Almeida, Rio de Janeiro de 1870. Lisboa: Fundação Calouste Glubenkian, 1985.

Bibliography

Abrahão, J. D. (2015). Degredo e Reinserção Social de Degredados, Angola (Século XVIII). XXVIII Simpósio Nacional de História. http://www.snh2015.anpuh.org/resources/anais/39/1454341750 ARQUIVO Trabalho da Anpuh.pdf

Abrahão, J. D. (2014). Vadios, ladrões, assassinos e outros degredados (angola, século XVIII) [Trabalho de conclusão de curso, Universidade Federal Rural do Rio de Janeiro].

Abreu, L. (2014). O Poder e os Pobres. Dinâmicas políticas e sociais da pobreza e da assistência em Portugal (séculos XVI a XVIII). Gradiva.

Alves, J. F. (2002). Imigração de galegos no Norte de Portugal (1500-1900). Algumas notas. In A. Eiras Roel e D. L. González Lopo (Coord.), Movilidade e migracións internas na Europa Latina. (pp.117-126). UNESCO.

Araújo, M. M. L. (1998). Pobres nas malhas da lei: a assistência aos presos nas Misericórdias de Vila Viçosa e Ponte de Lima. CADERNOS DO NOROESTE. Vol.11, (2), p. 83-114.

Amado, J. (2000). Viajantes involuntários: degredados portugueses para a Amazônia colonial. História, Ciência, Saúde - Manguinhos, vol. 6 (suplemento), 813-832.

Braga, P. D. (1999). Os forçados das galés. Percursos de um grupo marginalizado. In Barroca, M. J (Coord), Carlos Alberto Ferreira de Almeida in Memoriam, vol I. (pp.187-200). Faculdade de Letras da Universidade do Porto.

Cardoso, M. T. C. F. (2006). A Cadeia da Relação e a assistência prestada aos presos pela Misericórdia do Porto (1735-1740). NW noroeste. Revista de história. vol. I (2), 349-372.

Cruz, G. B. (1981). O movimento abolicionista e a abolição da pena de morte em Portugal. In Cruz, G. B, In Obras Esparsas. Estudos de História do Direito. Direito Moderno, vol. II, $2^{\circ}$ Parte. (pp.27-243). Universidade de Coimbra.

Coates, T. J. (1998). Degredados e Órfãs: colonização dirigida pela Coroa no Império Português, 1550-1775. Comissão Nacional para as Comemorações dos Descobrimentos Portugueses.

Correia. E. (1977). A Evolução Histórica Das Penas. Boletim da Faculdade de Direito, vol. LIII, 51-150.

Cortes, N. O. (1998). Clemência e punição régia. Uma análise a partir da produção legal seiscentista. CADERNOS DO NOROESTE. Vol. 11, (1), p. 87-124.

Costa, E. V. (1998). Primeiros povoadores do Brasil: o problema dos degredados. Revista Textos de História, vol. 6, $\mathrm{n}^{\circ} 1$ e $2,76-100$.

Esteves, A. (2015) Crimes e criminosos no Norte de Portugal: o Alto Minho oitocentista. Editorial Cáritas.

Esteves, A. (2014). La violencia en los espacios familiares rurales de Portugal. La región del Alto Miño, siglos XVIIIXIX. Historia Contemporánea, 49, 595-616.

Esteves, A. (2011). A duas palavras, três porradas: a violência verbal como expressão de conflituosidade social no Alto Minho de oitocentos. In F. M. Ferreira. F. A. Mendes e J. V. Capela (Coords.). Justiça Na Res Publica (sécs. XIX-XX) Ordem, direitos individuais e defesa da sociedade, vol.2. (pp.125-156). CITCEM- Centro de Investigação Transdisciplinar "Cultura, Espaço e Memória"

Esteves, A. (2010). Entre o crime e a cadeia: violência e marginalidade no Alto Minho (1732-1870) [Tese doutoral, Universidade do Minho].

Garcia, P. R. S. (2003). Degredados filhos do Reino: o envio de degredados para a Amazônia entre 1750 e 1800. Planeta Amazônia: Revista Internacional de Direito Ambiental e Políticas Públicas, n.4, 37-44.

Godinho, V. M. (1975). A Estrutura da Antiga Sociedade Portuguesa. Arcádia.

González Lopo, D. L. (2003). Migraciones históricas de los gallegos en el espácio peninsular (siglos XVI-XIX). Obradoiro de Historia Moderna, 12, 167-182.

Hespanha, A. M. (1987). Da «lustitia» à «Disciplina», Textos, Poder e Política Penal no Antigo Regime. Anuario de historia del derecho español, N. 57, 493-578.

Le Goff, J. (1985). O maravilhoso e o quotidiano no Ocidente medieval. Edições 70.

Leite, A. L. (2019). Contributo para a Evolução Histórica das Penas Substitutivas. Revista Jurídica Luco-Brasileira, Ano $5, n^{\circ} 3,153-257$.

Lessa, A. (2016). O livro dos degredados e as fontes para o estudo da punição no Império Português do século XVIII. Departamento de História, Universidade Federal do Rio Grande do Sul.

Lopes, M. A. (2015). Mulheres condenadas à Morte em Portugal: de 1692 à abolição da Pena Última. In Braga, M. R. M. D., Torremocha Hernández, M. (Coord.), As mulheres perante os tribunais do Antigo Regime na Península Ibérica. (pp. 119-145). Imprensa da Universidade de Coimbra. DOI: http://dx.doi.org/10.14195/978-989 -26 -1033-7_6

Lopes, M. A. (2013). Pobres Presos de Coimbra. Perfis e vivências à luz das Inquirições da Misericórdia (1720-1732). In I Congresso Histórico Internacional. As Cidades na História: População, vol. III, Cidade Moderna I, 179-202. 
Lopes, M. A. (2010). Cadeias de Coimbra: espaços carcerários, população prisional e assistência aos presos pobres (1750-1850). In M. M. L. Araújo, F. M. Ferreira, A. Esteves (Orgs.). Pobreza e assistência no espaço Ibérico (séculos XVI-XIX). (pp. 101-125). CITCEM - Centro de Investigação Transdisciplinar "Cultura, Espaço e Memória".

Magalhães, A. (2017). Os assistidos: formas e beneficiários da actuação das Misericórdias, (1498-1910). In J. P. Paiva, (Coord). Portugaliae Monumenta Misericordiarum (pp. 119-161), vol. 10. Centro de Estudos de História Religiosa; União das Misericórdias portuguesas.

Marques, C. (2008). Notas sobre o degredo no império português: a colônia americana. Anais do XIX Encontro Regional de História: Poder, Violência e Exclusão. ANPUH/SP-USP. https://www.anpuhsp.org.br/sp/downloads/CD\%20XIX/PDF/Paineis/Carolina\%20Marques.pdf.

Neves, L. (2017). Dar pousada aos peregrinos»: a assistência fornecida pelas Santas Casas da Misericórdia aos viajantes, na região do Minho, durante a Época Moderna (século XVII-XVIII). (Dissertação de Mestrado, Universidade do Minho).

Oliveira, M. T. E. (1998). As Misericórdias e a assistência aos presos. CADERNOS DO NOROESTE. Vol.11, (2), p. 65-82.

Oliveira Costa, T. T. (2018). "Nas terras remotas o Diabo anda solto": degredo, Inquisição e escravidão no mundo atlântico português (séculos XVI a XVIII) [Dissertação de Mestrado, Universidade Federal de Minas Gerais].

Palacin, L. (1971). As comunicações marítimas no Brasil durante o século XVI. In Paula, Eurípedes Simões De (org.). Portos, Rotas e Comercio - Anais do V Simpósio Nacional dos Professores Universitários de História. vol. I, São Paulo: XXXV Coleção da Revista de História. p.187-198. 1971.

Pantoja, S. (2004). Inquisição, degredo e mestiçagem em Angola no século XVIII, Revista Lusófona De Ciência Das Religiões, Ano III, n5/6, 117-136.

Pieroni, G. (2002). Banidos para o Brasil: A pena do degredo nas Ordenações do Reino. Justiça \& História, v. 1, n. 1 e 2. https://bdjur.stj.jus.br/jspui/bitstream/2011/65403/banidos para brasil pieroni.pdf.

Pontarolo, F. (2018). Povoar e Punir: especificidades do degredo interno no Brasil oitocentista. https://revistas.ufpr.br/direito/article/viewFile/7001/4979

Rodrigues, T. F. (1994). As estruturas populacionais. In J. Mattoso (Dir.), História de Portugal: no alvorecer da modernidade vol. III, (pp. 197-241). Editorial Estampa.

Serrão, J. V. (1982) História de Portugal: O despotismo iluminado, (1750-1807), vol. VI. Editorial Verbo.

Serrão, J. V. (1980). História de Portugal- A Restauração e a Monarquia Absoluta (1640-1750), vol. V. Editorial Verbo.

Serrão, J. V. (1979). História de Portugal- Governo dos reis espanhóis (1580-1640), vol. IV. Editorial Verbo.

Serrão, J. V. (1998). O Quadro Humano. In J. Mattoso (Dir.), História de Portugal - O Antigo Regime (1620-1807), vol. IV, (pp. 43-65). Editorial Estampa.

Toma, M. (2013). A pena do degredo em Portugal. In XXVII Simpósio Nacional de História. Conhecimento histórico e diálogo social. http://www.eeh2014.anpuh-rs.org.br/resources/anais/27/1364756302 ARQUIVO anpuh2.pdf

Toma, M. (2011). A pena de degredo e a construção do império colonial. http://www.humanas.ufpr.br/portal/cedope/files/2011/12/A-pena-de-degredo-e-a-construção-doimpério-colonial-Maristela-Toma.pdf.

Torres, S. (2006). O cárcere dos indesejáveis: Degredados na Amazônia portuguesa (1750-1800) [Dissertação de Mestrado, Pontifícia Universidade Católica de São Paulo].

Wagner, A. P. (2007). A administração da África Oriental portuguesa na segunda metade do século XVII: Notas para o estudo da região de Moçambique. História Unisinos, 11(1), 72-83.

Zocca, M. (2004). Donne delinquenti. Storie de streghe, ribelli, rivoltose, tarantolate. Edizioni Simone.

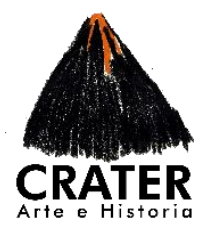

Cómo citar este artículo:

Valente Neves, L. A. (2021). From Portugal to the Colonies: Characteristics of Portuguese Exiles at the End of the 18th Century. CRATER, Arte e Historia(1), 54-71. 